\title{
研究課題別事後評価結果
}

1. 研究課題名「次世代合成のための多機能集約型触媒の構築」

2. 研究代表者名及び主たる研究参加者名 (研究機関名・職名は研究参加期間終了時点)

研究代表者

香月 勗 (九州大学大学院理学研究院 教授)

主たる研究参加者

金政 修司（九州大学先導物質化学研究所生命有機化学部門）

細見 彰（筑波大学数理物質科学研究科・化学系

(現大学評価·学位授与機構))

伊藤 克治 (福岡教育大学)

3. 研究内容及び成果

$3-1$. 研究の目的

現在の高度な文明は多様な機能性物質の利用の上に成立している。それらの物質の多くは化 石燃料を出発原料とする多段階物質変換により供給されているが、物質変換法の効率が不十分 なために望ましくない副生成物の生成を伴うことが多く、地球環境に大きな負荷をかけている。また、 最適化されていない条件下での反応はエネルギーの浪費をももたらすことにもなっている。このよう に未成熟な合成化学の利用は、枯渇が心配されている化石燃料の過剩消費の一因ともなっており、 合成化学の効率化は緊急の課題である。

\section{$3-2$. 研究構想}

本研究では、新規触媒の導入によって 1)合成反応の立体、化学、位置選択性の向上、2)酸素や 過酸化水素などの小分子の利用による反応の原子効率の向上、3)触媒の耐久性改善に基づく触 媒回転数の向上、4)反応条件の温和化による反応エネルギーの節減あるいはクリーンエネルギー である光エネルギーの利用、5)反応剤の活性化基に由来する副生成物のクリーン化を目標として研 究を開始した。

この問題を解決するために 1)触媒に異なる複数の機能を付与し素反応に応じて触媒の機能を 使い分け、反応の選択性の向上と反応条件の至適化(温和化)を試みた(香月グループ分担)。同 時に 2)強力なルイス酸触媒であるカチオン性錯体を対象として、可逆的に配位可能な中性置換基 の導入による耐久性錯体触媒の構築を検討した (金政グループ分担)。さらに 3)より直截的な反応 経路の開発を目的として新規活性種の創製を試みた(細見グループ分担)。

$3-3$. 研究の成果

3-3-1. 多機能集約型触媒および小分子の活用による環境調和型不斉合成反応 
分子触媒に複数の触媒機能を付与寸る試みは多様な触媒活性を示す各種遷移金属のサレン 錯体の動的分子挙動とアピカル配位子効果を制御することによって行われ、小分子の酸素 (大気) を用いるアルコールの酸化や過酸化水素をもちいるスルホ酸化ならびに Baeyer-Villiger 反応、さら にはアジド化合物を用いるアジリジン化反応などが室温にて高エナンチ才選択的に進行することが 見いだされた。なお、酸素酸化の反応機構は、その速度論および反応における速度論的同位体効 果の詳細な解析に基づいて、その触媒サイクルは3つの素反応よりなることが明らかにされた。さら に配位子効果を利用して律速段階の制御が可能であることが明らかにされて、多機能集約型触媒 の有用性が確認された。特に、配位子の柔軟性とキラリティーを考慮して、自己組織化を伴う二核錯 体の新規構築法が見いだされた。この新たな手法を用いて、サレンよりも柔軟なサラレン配位子を用 いて二核のジ- $\mu$-オキソチタン(サラレン) 錯体を構築し、過酸化水素水を用いるエポキシ化で初め て高エナンチオ選択性と同時に高触媒回転数を達成することができた。本法は、工業的実用化が 期待されている。(香月グループ分担)

3-3-2. カチオン性錯体を利用した耐久性触媒

ジベンゾフランビス (オキサゾリン) 配位子 $[\mathrm{DBFOX}]$ の亜鉛錯体を基本骨格として触媒の開発を 行い、オキサゾリン部の5位に置換基を導入して非会合性のカチオン性錯体を構築した。これを用 い 1,3-双極子と親双極子を同時に捕捉して環状付加反応を行わせ、高エンド、高エナンチオ選択 性を達成した。さらにオキサゾリン部に $o$-ヒドロキシベンジル基をもつ銅錯体 $[\mathrm{DBFOX} / \mathrm{HOBu}$-銅錯 体乃゙アミンのような塩基性求核剤の存在下でもルイス酸性を示すことを見出し、アミンの共役付加で 高エナンチ才選択性を達成することができた。特に、酸触媒と塩基触媒は速やかに塩形成を行うた めに、一般的に両者を共存させて用いることはできない。カチオン性ニッケル錯体は塩基の存在下 でもルイス酸性を示すことが見出され、求核剂と求電子剤の触媒的二重活性化が可能なことが明ら かにされた。この手法を用いて高エナンチ才選択的な各種の不斉マイケル反応が開発されつつあり、 今後の発展が期待される。(金政グループ分担)

$3-3-3$. 新規活性種の創製と不斉合成反応

有機ケイ素化合物と銅化合物の金属交換、鉄触媒存在下での有機リチウムあるいは有機マグ ネシウム反応剂ジインへの付加反応によって、アルキニルあるいはアルケニルアニオンの発生を 行ない、多様なアルキンやアルケン類の効率的合成法を開拓した。特に後者は有機金属の使い 分けによって $E / Z$ 選択的にアルケニルアニオンの生成が可能で有り。立体選択的アルケンの合 成を可能にした。特に、通常ルイス酸と求核剤の反応ではシリルエノールエーテルのような温和な 求核剤が用いられるが、有機マンガンはルイス酸と直接反応して失活することなく活性化された 求電子剤に作用することが見出された。この有機マンガン-Lewis 酸複合系 (複合反応剤) 系は、 カルボカチオンとカルボアニオンの共存系とも考えることができ、これらの特徵に基づく合成反応 の設計が今後期待される。(細見グループ分担) 3-3-4. 歪夕をもつ多基質補足型高活性触媒

平成13年度より歪み構造をもつ遷移状態の制御を目指した研究に着手し、 $\mathrm{P}-\mathrm{N}$ 型配位子の設 計を行い、高エナンチオ選択的 Baeyer-Villiger 反応やへテロ環式化合物の不斉合成法が達成さ 
れた。特に、ジー $\mu$-オキソチタン(サラレン)錯体に引き続いて、三角両錐構造というアルミニウム(サ ラレン)錯体が開発され、一般的なヒドロホスホニル化が達成された。その特異な構造から、他のルイ ス酸触媒への応用が期待される。（伊藤、香月グループ分担）

4. 事後評価結果

4-1. 外部発表(論文、口頭発表等)、特許、研究を通じての新たな知見の取得等の研究成果の状況 グループ全体として海外102件の論文発表を行った。招待講演は国内36件、海外40件、口頭 発表、ポスター発表は内容的に重複しているものを除き、国内249件、海外38件である。特許出 願は国内21件、海外11件であった。

4-2. 成果の戦略目標・科学技術一の貢献

不斉エポキシ化、不斉スルホン化のような一般的に困難な不斉酸化反応の新規触媒の研究で は第一人者であり、新しい触媒設計法や反応制御概念を見いだすことができた。特に、過酸化水 素や酸素のような酸化剂による選択性の高い酸化反応の触媒に関して重要な知見を得ており、特 許出願および、ライセンス契約にも繋げている。本研究が目指している環境調和型の化学合成反 忘は、環境・エネルギーの課題とも絡み、引き続き重要な研究テーマであり、さらなる進展が期待さ れる。

サブグループもそれぞれに優れた研究成果を挙げていると言えるが、グループ間の連携・シナ ジー効果による研究成果への貢献度については今ひとつ見えない。

4-3. その他の特記事項(受賞歴など)

香月勗研究代表者は、第 54 回日本化学会賞「金属錯体を用いる触媒的不斉合成反応の開 拓」(平成13年度)「モレキュラーキラリテイ賞」(平成13年)および第4回 Ryoji Noyori Award (平成 17年)を受賞。また、共同研究者のうち、細見彰が「第 55 回日本化学会賞」「ケイ素関連金属新 反応剂の開拓と実践的有機合成への応用」(平成 14 年)、入江亮が「文部科学大臣表彰 若手 科学者賞」“有機合成化学分野における触媒的不斉酸化反応の研究” (平成17年)を受賞した。 